\title{
Nicotine exacerbates reproductive biomarkers via generation of free radicals in female Wistar rats: Protective role of Quercetin
}

\author{
Ola D. ${ }^{1}$, *Adeyemi D.H. ${ }^{1}$, Obembe O.O. ${ }^{1}$, Ogooluwa A.A. ${ }^{1}$, Ladele M.O. ${ }^{1}$, Owonikoko S.T. ${ }^{2}$, \\ Olowu R.', Oyeyipo I.P.
}

\begin{abstract}
Background: Nicotine has been widely reported to generate free radicals in several organs of the body. Therefore, this study investigated the ameliorative potentials of Quercetin on selected reproductive biomarkers in female Wistar rats.

Methods: Forty female rats were randomly divided into five groups $(\mathrm{n}=8)$ which were treated as follows: Group I (CN) received normal saline ( $1 \mathrm{ml} / \mathrm{kg}$ bwt); Group II (LN) received nicotine $(0.5 \mathrm{mg} / \mathrm{kg}$ bwt) only; Group III (HN) received nicotine $(1.0 \mathrm{mg} / \mathrm{kg}$ bwt) only; however, Groups IV (LNA) and V (HNA) received 0.5 and $1.0 \mathrm{mg} / \mathrm{kg}$ of nicotine with $20 \mathrm{mg} / \mathrm{kg}$ of quercetin respectively. All administration were done orally and lasted 28 days.

Results: Nicotine significant reduction in the bioavailability of estrogen and progesterone in the treated rats when compared to control. Furthermore, relative to the control group, nicotine administration resulted in significant elevation in MDA and consequently caused significant reduction in the antioxidant enzymes (SOD and CAT) activities. However, quercetin treatment ameliorated these alterations.
\end{abstract}

Conclusion: Quercetin dampens the reproductive distruptive effects exerted by nicotine through antioxidative mechanism in female Wistar rats.

Keywords: Nicotine, Quercetin, Oxidative stress, Hormone, Reproductive toxicity.

\author{
*Corresponding author \\ Adeyemi DH. \\ ORCID-NO: http://orcid.org/0000-0003-4339-8541 \\ Email: bobdare2013@gmail.com
}

${ }^{1}$ Department of Physiology, Faculty of Basic Medical Sciences, College of Health Sciences, Osun State University, Osogbo, Osun State, Nigeria.

${ }^{2}$ Department of Physiology, Faculty of Basic Medical Sciences, College of Medicine, University of Ibadan, Ibadan, Nigeria. 


\title{
La nicotine exacerbe les biomarqueurs de la reproduction via la génération des radicaux libres chez les rats Wistar femelles : Rôle protecteur de la quercétine
}

\author{
Ola D. ${ }^{1}$, *Adeyemi D.H. ${ }^{1}$, Obembe O.O. ${ }^{1}$, Ogooluwa A.A. ${ }^{1}$,Ladele M.O. ${ }^{1}$, Owonikoko S.T. ${ }^{2}$, \\ Olowu R. ', Oyeyipo I.P. ${ }^{\prime}$
}

\section{Résumé}

Contexte de l'étude : Il a été largement rapporté que la nicotine génère des radicaux libres dans plusieurs organes du corps. Par conséquent, cette étude a examiné les potentiels d'amélioration de la quercitrine sur des bios marqueurs de reproduction sélectionnés chez des rats Wistar femelles.

Méthode de l'étude : Quarante rats (40) femelles ont été répartis au hasard en cinq groupes ( $\mathrm{n}=8$ ) qui ont été traités comme suit : le groupe $\mathrm{I}(\mathrm{CN})$ a reçu une solution saline normale $(1 \mathrm{ml} / \mathrm{kg}$ de poids corporel $) ; \mathrm{Le}$ groupe II (LN) n'a reçu que de la nicotine $(0,5 \mathrm{mg} / \mathrm{kg}$ de poids corporel); Le groupe III (HN) n'a reçu que de la nicotine $(1,0 \mathrm{mg} / \mathrm{kg}$ de poids corporel); cependant, les groupes IV (LNA) et V (HNA) ont reçu respectivement 0,5 et $1,0 \mathrm{mg} / \mathrm{kg}$ de nicotine avec $20 \mathrm{mg} / \mathrm{kg}$ de quercétine. Toutes les administrations ont été faites par voie orale et ont duré 28 jours.

Résultat de l'étude: Réduction significative de la biodisponibilité des œstrogènes et de la progestérone chez les rats traités par rapport au contrôle. De plus, par rapport au groupe témoin, l'administration de nicotine a entraîné une élévation significative de la MDA et, par conséquent, entraîné une réduction significative des activités des enzymes antioxydantes (SOD et CAT). Cependant, le traitement à la quercétine a amélioré ces altérations.

Conclusion : La quercétine atténue les effets perturbateurs de la reproduction exercés par la nicotine par le biais d'un mécanisme antioxydant chez les rats Wistar femelles.

Mots-clés : Nicotine, quercétine, stress oxydatif, hormone, toxicité pour la reproduction

\author{
*Corresponding author \\ Adeyemi DH. \\ ORCID-NO: http://orcid.org/0000-0003-4339-8541 \\ Email:bobdare2013@gmail.com
}

\footnotetext{
${ }^{1}$ Department of Physiology, Faculty of Basic Medical Sciences, College of Health Sciences, Osun State University, Osogbo, Osun State, Nigeria.

${ }^{2}$ Department of Physiology, Faculty of Basic Medical Sciences, College of Medicine, University of Ibadan, Ibadan, Nigeria.
} 


\section{INTRODUCTION}

Exposure to certain lifestyles and behaviour has been reported to adversely affect people's health. This may not be separated from one of the challenges that accompany the advent of western societal influence (1) on people's health. Lifestyle habits such as tobacco consumption which include smoking, sniffing, chewing among others could be inimical to one's wellbeing thus adversely affecting several body systems. Converging lines of evidence have revealed that cigarette smoking is considered the second most prevalent cause of death worldwide. Tobacco intake whether actively or passively has been reported to adversely affects various body organs (2). Globally, studies have shown that about $60 \%$ of non-communicable diseases emanates from tobacco smoking (3). Tobacco smoke remains the main source of nicotine exposure to humans. Nicotine, the active chemical found in cigarette, have been documented to reduce body weights (4), causes respiratory impairments, cancer, coronary heart disease, reproductive dysfunction (5) among others.

In humans, continuous exposures to nicotine have been reported to induce oxidative stress. An increase level of reactive oxygen species and as well as lipid peroxidation have been well documented in cigarette smokers (6). Reactive Oxygen Species (ROS) are group of radicals consisting of unpaired electrons generated from cellular functional processes. It has previously been reported that the products of lipid peroxidation increases as exposure to nicotine increases and this may cause irreversible mitochondrial and/or cell membrane damage (7). Nicotine induces oxidative stress in-vivo and invitro causing an imbalance in pro-oxidant and antioxidant enzymes activities in blood cells, plasma and body tissues.

Conversely, the use of exogenous antioxidants to mitigate the damage associated with the generation of free radicals has emerged a promising field in the treatment of diseases. The beneficial effects of flavonoids to ameliorate several diseases have been well documented (8). Quercetin, a prominent member of the flavonoids family is known to confer both antioxidants and anti-inflammatory properties when consumed. It is widely found in fruits, herbs, vegetables particularly onions and several other plants with medicinal benefits (9). Furthermore, several studies have reported the therapeutic effects of quercetin, such as protection against osteoporosis, cancer, cardiovascular disease as well addressing reproductive dysfunctions associated with oxidative stress. Based on these reports, quercetin may be considered as an effective and easily obtainable plant-derived ingredient to counter the health disorders that are caused by oxidative pollutants such as nicotine consumption. Therefore, this study investigated the ameliorative potentials of quercetin on nicotine induced reproductive toxicity in female Wistar rats.

\section{MATERIALS AND METHOD Drug}

Nicotine hydrogen tartrate (Sigma Aldrich, South Africa) and Quercetin (Sigma chemical company, USA) were used in this study. Both were diluted in distilled water to achieve the desired concentration and freshly prepared before administration.

\section{Animals}

Forty female rats $(130-150 \mathrm{~g})$ obtained and kept in the Central Animal House of Osun State University, Osogbo were used in this study. All animals were housed in well-ventilated plastic cages with a wire opening and kept under standard laboratory conditions of $12 \mathrm{hr} / 12 \mathrm{hr}$ light and dark cycle at $37^{\circ} \mathrm{C}$ room temperature. They were fed with standard pellet diet and provided water ad libitum. Animal care and experimental protocols were carried out in accordance with the guidelines of U.S National Institute of health on the care and use of laboratory animals.

\section{Experimental Design}

Animals were randomly divided into five groups $(n=8)$ and were treated as follows:

Group I: received $1 \mathrm{ml} / \mathrm{kg}$ of normal saline and served as control.

Group II: received $0.5 \mathrm{mg} / \mathrm{kg}$ of nicotine only. Group III: received $1.0 \mathrm{mg} / \mathrm{kg}$ of nicotine only. Group IV: were co-administered with $0.5 \mathrm{mg} / \mathrm{kg}$ of nicotine and $20 \mathrm{mg} / \mathrm{kg}$ of quercetin.

Group V: were co-administered with $1.0 \mathrm{mg} / \mathrm{kg}$ of nicotine and $20 \mathrm{mg} / \mathrm{kg}$ of quercetin.

All administration was done via oral gavage and lasted 28 days.

\section{SPECIMEN COLLECTION}

Twenty-four hours after last administration, animals were anaesthetized and sacrificed. Blood sample was collected through cardiac puncture for biochemical estimations while organs of interest were harvested and 
weighed immediately. Thereafter, blood collected was spun at 3,000 rpm for 15 minutes and serum obtained was used for the determination of hormones concentrations and oxidative stress parameters.

\section{Hormonal Assay}

Estrogen and progesterone levels were estimated using an enzyme based immune assay system. An enzyme based immunoassay test kit (Rapid Lab) was obtained from London, United Kingdom and contain the enzyme based immune assay substrate reagent and quality control sample

\section{Determination of oxidative stress markers}

Oxidative stress was estimated using spectrophotometry method as follows-

Malondialdehyde using the thiobarbituric acid test procedure (10), Superoxide dismutase using the Sigma- Aldrich Superoxide dismutase assay kit II (11) and Catalase level was measured using the Ultraviolet Spectrophotometric method (12).

\section{Statistical Analysis}

Data obtained were expressed as Mean \pm Standard Error of Mean (S.E.M) and analyzed using one way analysis of variance (ANOVA). Statistical significance was considered at $\mathrm{p} \leq$ 0.05 .

\section{Results \\ Effects of nicotine and quercetin administration on body weight changes and visceral organs weight in female Wistar rats.}

The result shows that the mean body weight of animals was comparable throughout the period of administration (Table 1). Conversely, there was no significant difference in the mean weight of accessory organs in all the treated groups as compared with control (Table 2 ). The ovarian and uterine weights also remain comparable in all the groups (Figure 1).

Effects of nicotine and quercetin administration on female reproductive hormones in Wistar rats.

Compared with the control group, there were significant decreases $(\mathrm{P}<0.05)$ in serum estrogen level of groups that received low dose of nicotine (LN) and high dose of nicotine (HN) respectively. Relative to $\mathrm{LN} \& \mathrm{HN}$, only the group that received high nicotine with quercetin showed significance increase $(\mathrm{P}<0.05)$ in serum estrogen level (Figure 2).

Conversely, the result showed a significance decrease $(\mathrm{P}<0.05)$ in serum progesterone level in animals treated with High Nicotine (HN) and High Nicotine + Quercetin (HNA) respectively as compared with control (Figure 3).

\section{Effects of nicotine and quercetin administration on oxidative stress markers in Wistar rats.}

Compared with the control $(\mathrm{CN})$, there were significant increase in the serum level of MDA in LN and HN (Figure). However, relative to $\mathrm{CN}, \mathrm{LN}$ and $\mathrm{HN}$, there were significant decrease in MDA level of groups that were cotreated with quercetin (LNA and HNA) respectively (Figure 4). Furthermore, the activity of catalase was significantly decreased in $\mathrm{LN}$ and HN compared with control; however, the activity of CAT was significantly elevated in rats cotreated with quercetin (LNA and HNA) as compared with $\mathrm{CN}, \mathrm{LN}$ and $\mathrm{HN}$ (Figure 5) Moreover, there was a significant increase in the activity of superoxide dismutase (SOD) of rats co-treated with quercetin (LNA and HNA) as compared with $\mathrm{CN}$ and $\mathrm{HN}$ only (Figure 6).

\section{DISCUSSION}

The present study investigated the therapeutic potential of quercetin on nicotineinduced female reproductive toxicity. Numerous adverse effects of nicotine have been widely reported in humans thereby contributing to a variety of illnesses and pathological conditions $(13,14,15)$. The anti-estrogenic effects of nicotine in women who smokes cigarette have also been documented $(16,17)$. Nicotine, the active chemical, found in tobacco and cigarette smoke have been widely reported to generate a wide range of xenobiotics which include oxidants and oxygen free radicals that can ignite lipid peroxidation and consequently promote oxidative damage. Similarly, oxidative stress has been implicated in the pathogenesis of various body diseases including female reproductive dysfunction (18). However, the use of exogenous antioxidants to mitigate the damage(s) associated with generation of free radicals has emerged a promising field in the treatment of diseases. Interestingly, quercetin, a prominent exogenous antioxidants is commonly found in fruits, onions and several other plants with medicinal benefits (19). Conversely, the results obtained from this study demonstrates that nicotine administration induces female reproductive dysfunction as evident by reduced levels of estrogen, 
progesterone, and increased oxidative stress. However, these reproductive biomarker alterations were counteracted by quercetin intervention. Reactive oxygen species have been considered the group of radicals that consist unpaired electrons which impaired cellular functioning. Peroxidation of membrane lipids alters membrane fluidity and elasticity thus impaired cellular functioning and consequently cell damage. An elevated level of MDA has been considered a pivotal biomarker of oxidative stress. The increase in MDA level has been documented to be inversely proportional to sex hormones bioavailability. Increased oxidative stress decreases cell viability, destroy tissues and consequently disrupt steroidogenesis (20). The elevated MDA levels might be responsible for reduction in both estrogen and progesterone observed in this study. Ordinarily, optimal reproductive functions are controlled by complex interactions between the reproductive organs and sex hormones. However, the reduction in the sex hormones (estrogen and progesterone) observed in this study is unsurprising as several studies have revealed the anti-estrogenic $(21,22)$ and anti-progesterone effects of nicotine in female albino rats (23). Interestingly, the supplementation of quercetin to nicotine exposure counteract and improve reduction in sex hormones and oxidative stress in the rats thereby substantiates the antioxidants and antiinflammatory properties of this agent (24). Likewise, it has been documented that quercetin modulates ovarian functions, regulates steroidogenic activity, helps to improve hormonal indices (25) and this is in consonance with the present study. Overtime, the decrease in activities of the antioxidant enzymes have been suggested to significantly contribute to generation of free radicals such as up-regulation of superoxide anion or hydrogen peroxide which eventually culminates into oxidative stress (26). Similarly, a decrease in endogenous antioxidant enzyme, superoxide dismutase (SOD) is a marker for oxidative stress (27). In this study, there was a marked decrease in SOD activity of rats that were exposed to nicotine only. However, intervention with quercetin significantly increased this enzyme activities as compared with control and nicotine treated only. The observed increase in this antioxidant enzyme could suggest that this enzyme was readily available to mitigate the adverse effects of the reactive oxygen species as evident by the elevated MDA levels noticeable in this study.

Catalase (CAT) is a potent antioxidant enzyme that functions to neutralize the adverse effects of hydrogen peroxide and a decrease in this enzyme indicate oxidative stress especially when MDA increases as well $(28,29)$. In the study, there was a significant decrease in the CAT level of rat treated with low dose of nicotine, high dose of nicotine as compared with control. This indicates that the activities of this free radical scavenging enzyme increases oxidative stress, which is in consistent with previous studies (30). However, co-administration with quercetin synergistically improves CAT activities as compared with rats exposed to nicotine only. This could probably suggests that quercetin supplementation enhances antioxidant enzymes as documented in previous studies $(31,32)$ thus suggesting the ameliorative potentials of this natural agent.

\section{CONCLUSION}

The present study demonstrates that oral quercetin administration dampens nicotineinduced female reproductive toxicity by attenuating oxidative stress and other reproductive biomarkers. Therefore, the consumption of quercetin during nicotine exposure improves some reproductive biomarkers in female Wistar rats. Further studies are required to explore other mechanisms affecting reproductive functions following nicotine exposure.

Conflict of Interest: The authors declare no conflict of interest.

Acknowledgment: The authors acknowledged the support and assistance of laboratory staff members of Physiology Department, College of Health Sciences, Osun State University, Osogbo.

\section{REFERENCES}

1. Cameron AJ, Welborn TA, Zimmet PZ, Dunstan DW, Owen N, Salmon J, et al. (2003). Overweight and obesity in Australia: the 19992000 Australian Diabetes, Obesity and Lifestyle Study (AusDiab). Med J Aust 178,427-432.

2. Leone A. (2003). Relationship between cigarette smoking and other coronary risk factors in atherosclerosis: risk of cardiovascular disease and preventive measures. Curr Pharm Des 9,2417-2423.

3. Schraufnagel DE, Latif E.( 2014). Non-communicable diseases, tobacco, and The Union. Int J Tuberc Lung Dis; 18: 1139-40.

1. 4. Oyeyipo I.P., Yinusa Raji, Bolarinwa A.F.(2014). Nicotine Alters Serum Antioxidant Profile in Male Albino Rats. North American Journal of Medical Sciences Vol. 6 (4). 168-173.

4. Iranloye BO, Bolarinwa AF (2005) Effect of 
Nicotine administration on weight and histology of some vital viscera organs in female albino rats. J Physiol 567P, PC181.

5. Ashakumary, L., Vijayammal, P.L (1991). Lipid peroxidation in nicotine treated rats. J. Ecotoxicol. Environ. Monit. 1, 283-290.

6. Srinivasan KN, Pugalendi KV. (2000). Effect of excessive intake of thermally oxidized sesame oil on lipids, lipid peroxidation and antioxidants status in rats. Indian J Exp Biol ; 38 : 777-80.

7. Benowitz NL, Porchet H, Sheiner L, Jacob P (1988). Nicotine absorption and cardiovascular effects with smokeless tobacco use: comparison with cigarettes and nicotine gum. Clin Pharmacol Ther ;44 (1):23-28.

8. Wach A, Pyrzynska K, Magdelana B.(2007): Quercetin content in some food and herbal samples. Food Chemistry.100:699-704.

9. Uchiyama M., Mihara M.(1978). Determination of malondealdehyde precursor in tissues by thiobarbituric acid test. Analytical Biochemistry.86:271-278.

10. Sun M., Zigman S.(1978): An improved spectrophotometric assay for superoxide dismutase based on epinephrine autoxidation. Analytical Biochemistry. 90:81-89.

11. Aebi H.(1984): Catalase in vitro. Methods in Enzymology. 105:121-126

12. Wilkins JN, Carlson HE, Van Vunakis H, Hill MA, Gritz E and Jarvik ME (1982). Nicotine from cigarette smoking increases circulating levels of cortisol growth hormone.

13. Adeyemi DH, Oyeyipo IP, Akanbi KA,Oluwole T.(2018). Nicotine alters progesterone and estradiol levels during the first trimester of pregnancy in Wistar rats. JBRA Assisted Reproduction. 22(2):78-81.

14. Iranloye BO, Bolarinwa HF (2005) Effect of Nicotine administration on weight and histology of some vital viscera organs in female albino rats. J Physiol 567P, PC181.

15. Obembe OO, Olatoke TF, Atere TG (2019). Reproductive indices and oxidative stress biomarkers of male Wistar rats prenatally exposed to cigarette smoke. Nigerian Journal of Physiological Science. 34(1):091-098.

16. Aitken RJ, Koopman P, Lewis SE. Seeds of concern. Nature 2004;432(7013):48-52.

17. Wach A. Pyrznyska K, Biesaga M. (2007): Quercetin content in some food and herbal samples. Food Chemistry. 100:699-704.

18. Akindele OO, Kunle-Alabi OT, Adeyemi DH, Oghenetega BO, Raji Y.(2014): Effects of vitamin $\mathrm{E}$ and melatonin on serum testosterone level in sleep deprived Wistar rats. African Journal of Medicine and Medical Science.43: 295-304.
19. Iranloye BO, Bolarinwa AF (2009). Effect of nicotine administration on weight and some vital organs in female albino rats. Niger J Physiol Sci. $24: 7-12$

20. Adeyemi DH, Oyeyipo IP, Akanbi KA,Oluwole DT.(2018). Nicotine alters progesterone and estradiol levels during the first trimester of pregnancy in Wistar rats. JBRA Assisted Reproduction. 22(2):78-81.

21. Adeyemi DH, Oyeyipo IP, Akanbi KA,Oluwole T.(2018). Nicotine alters progesterone and estradiol levels during the first trimester of pregnancy in Wistar rats. JBRA Assisted Reproduction. 22(2):78-81.

22. Shah KN, Patel SS (2016). Phosphatidylinositide 3-kinase inhibition: a new potential target for the treatment of polycystic ovarian syndrome. Pharm Biol.54(6):975-83.

23. Shah KN, Patel SS (2016). Phosphatidylinositide 3-kinase inhibition: a new potential target for the treatment of polycystic ovarian syndrome. Pharm Biol. 54(6):975-83

24. Halliwell B. (2006): Oxidative stress and neurodegeneration: where are we now? Journal of Neurochemistry.97(6):1634-1658.

25. Akindele OO, Kunle-Alabi OT, Adeyemi DH, Oghenetega BO, Raji Y.(2014): Effects of vitamin $\mathrm{E}$ and melatonin on serum testosterone level in sleep deprived Wistar rats. African Journal of Medicine and Medical Science.43: 295-304.

26. Lambers DS, Clarke KE. (1996). The maternal and fetalphysiologic effects of nicotine. Semin. Perinatol. 20:115-126.

27. Akindele OO, Kunle-Alabi OT, Adeyemi DH, Oghenetega BO, Raji Y.(2014): Effects of vitamin $\mathrm{E}$ and melatonin on serum testosterone level in sleep deprived Wistar rats. African Journal of Medicine and Medical Science.43: 295-304.

28. Ashakumary, L., Vijayammal, P.L (1991). Lipid peroxidation in nicotine treated rats. J. Ecotoxicol. Environ. Monit. 1, 283-290.

29. Elik M, Serdaroğlu G, Özkan R. (2007). The investigation of antioxidant activities of myricetin and quercetin with different methods. FenEdebiyat Fakültesi Fen Bilimleri Dergisi. 28: 2-10

30. Doğan Z, Kocahan S, Erdemli E, Köse E, Yılmaz, Ekincioğlu Z, (2015). Effect of chemotherapy exposure prior to pregnancy on fetal brain tissue and the potential protective role of quercetin. Cytotechnology. 67: 1031-1038.

31. Oyeyipo I.P., Yinusa Raji, Bolarinwa A.F.(2014).Nicotine Alters Serum Antioxidant Profile in Male Albino Rats. North American Journal of Medical Sciences Vol. 6 (4);168173.

\section{How to cite this article:}

Ola D., Adeyemi DH., Obembe O.O., Ogooluwa A.A., Ladele M.O., Owonikoko S.T., Olowu R., Oyeyipo I.P. Nicotine exacerbates reproductive biomarkers via generation of free radicals in female Wistar rats: Protective role of Quercetin. Research Journal of Health Sciences, 2021, 9(4): 378-388 
Table 1: Effects of nicotine and quercetin administration on body weight changes and accessory organs weight in female Wistar rats.

\begin{tabular}{lll}
\hline Groups & Initial $\mathbf{( g )}$ & Final $(\mathbf{g})$ \\
\hline CN & $151.6 \pm 13.79$ & $155.0 \pm 13.46$ \\
LN & $143 \pm 8.40$ & $157.3 \pm 10.96$ \\
HN & $150.8 \pm 5.00$ & $168.2 \pm 4.02$ \\
LNA & $138.3 \pm 6.09$ & $157.0 \pm 9.46$ \\
HNA & $141.9 \pm 4.67$ & $158.2 \pm 3.19$ \\
\hline \multicolumn{2}{l}{ Values expressed as mean + SEM; $\mathrm{n}=8}$.
\end{tabular}

KEYS: CN - Control, LN - Low Nicotine,

HN - High Nicotine, LNA - Low Nicotine + Quercetin, HNA - High Nicotine + Quercetin.

Table 2: Effects of nicotine and quercetin administration on visceral organs weight in female Wistar rats.

\begin{tabular}{llllll}
\hline Groups & Heart $\mathbf{( g )}$ & Liver(g) & Lung $(\mathbf{g})$ & Kidneys $(\mathbf{g})$ & Spleen(g) \\
\hline CN & $0.63 \pm 0.06$ & $4.92 \pm 0.40$ & $1.31 \pm 0.08$ & $0.88 \pm 0.06$ & $0.60 \pm 0.10$ \\
LN & $0.60 \pm 0.03$ & $4.71 \pm 0.22$ & $1.60 \pm 0.11$ & $0.89 \pm 0.07$ & $0.71 \pm 0.04$ \\
HN & $0.66 \pm 0.05$ & $5.12 \pm 0.24$ & $1.70 \pm 0.08$ & $0.98 \pm 0.03$ & $0.60 \pm 0.02$ \\
LNA & $0.60 \pm 0.03$ & $4.98 \pm 0.27$ & $1.47 \pm 0.12$ & $0.92 \pm 0.06$ & $0.56 \pm 0.10$ \\
HNA & $0.60 \pm 0.03$ & $5.33 \pm 0.33$ & $1.53 \pm 0.72$ & $1.00 \pm 0.05$ & $0.51 \pm 0.03$ \\
\hline
\end{tabular}

Values expressed as mean \pm SEM; $n=8$.

KEYS: CN - Control, LN - Low Nicotine, HN - High Nicotine,

LNA - Low Nicotine + Quercetin, HNA - High Nicotine + Quercetin. 

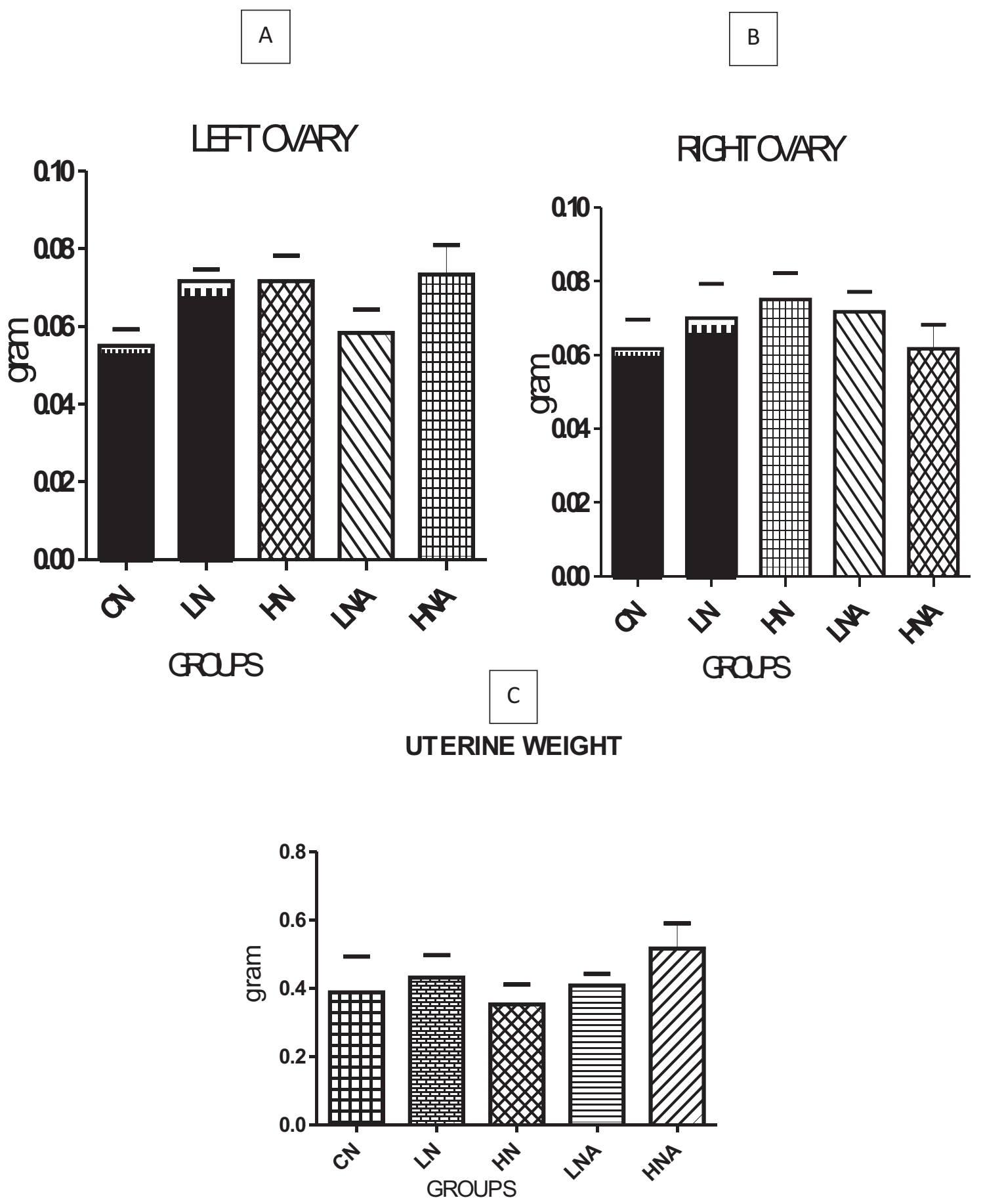

Figure 1(A, B \& C): Effects of nicotine and quercetin on ovarian and uterine weights in Wistar rats. Values expressed as mean \pm SEM; $n=8$.

KEYS: CN - Control, LN - Low Nicotine, HN - High Nicotine, LNA - Low Nicotine + Quercetin, HNA - High Nicotine + Quercetin 


\section{ESTROGEN}

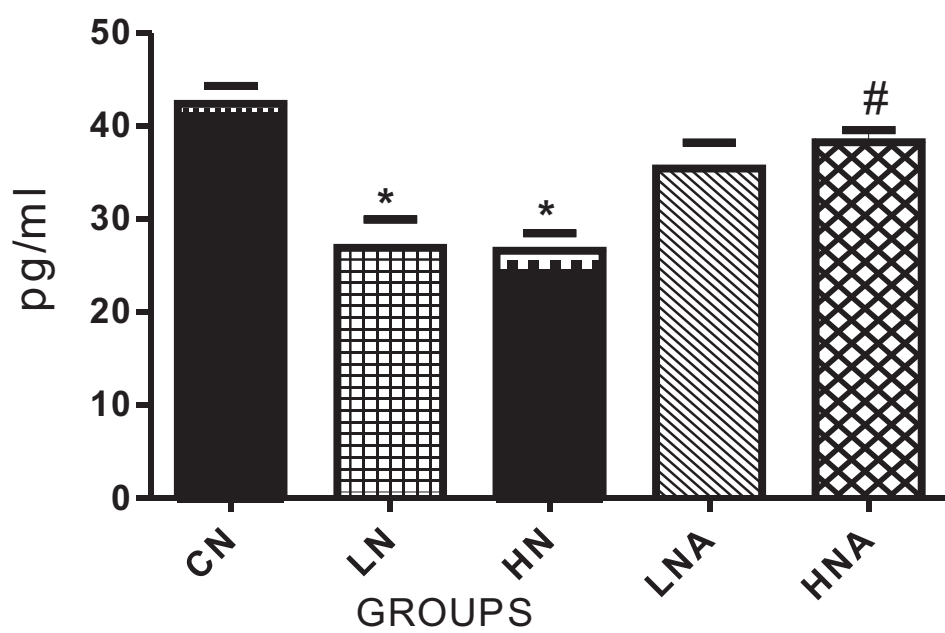

Figure 2: Effects of nicotine and quercetin on serum estrogen levels in Wistar rats.

Values expressed as mean $\pm \mathrm{SEM} ; \mathrm{n}=8 ;{ }^{* *} \mathrm{P}<0.05$ when compared with control,

${ }^{*} \mathrm{P}<0.05$ when compared with low nicotine, ${ }^{\#} \mathrm{P}<0.05$ when compared with high nicotine.

KEYS: CN - Control, LN - Low Nicotine, HN - High Nicotine,

LNA - Low Nicotine + Quercetin, HNA - High Nicotine + Quercetin.

\section{PROGESTERONE}

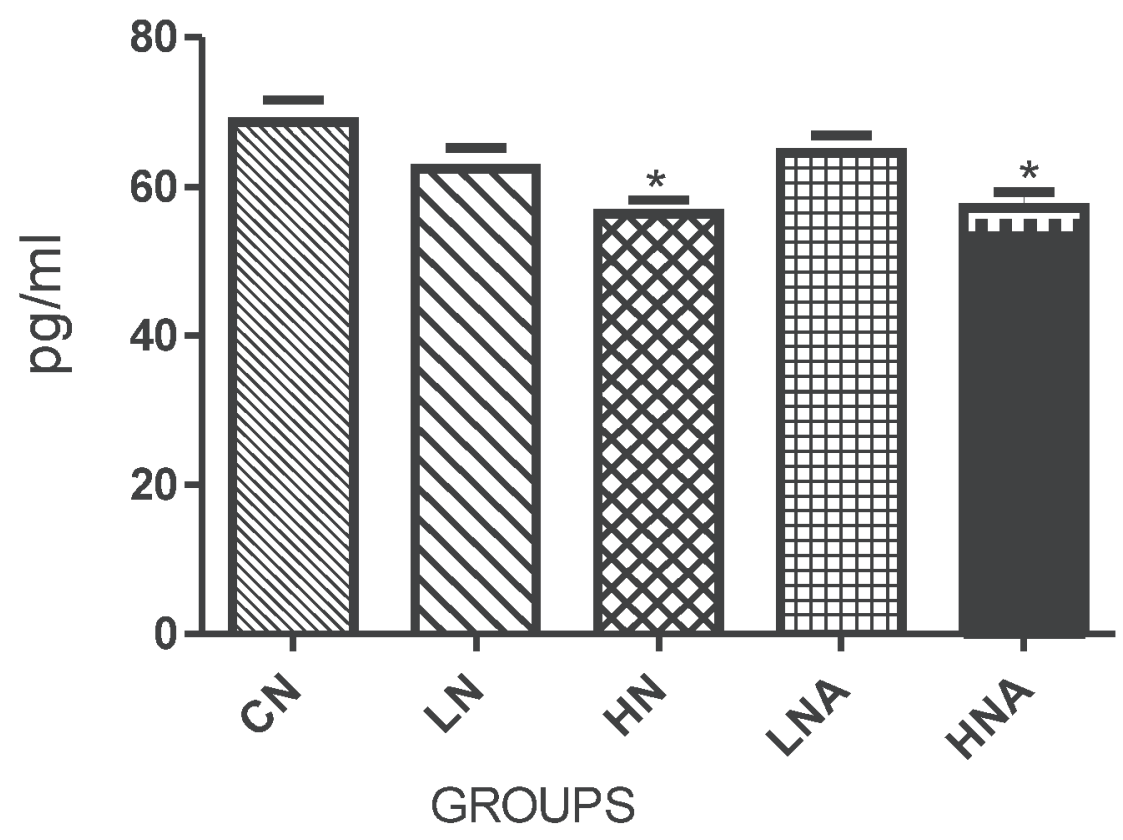

Figure 3: Effects of nicotine and quercetin on serum progesterone levels in Wistar rats. Values expressed as mean $\pm \mathrm{SEM} ; \mathrm{n}=8 ;{ }^{* *} \mathrm{P}<0.05$ when compared with control,

${ }^{*} \mathrm{P}<0.05$ when compared with low nicotine, ${ }^{\#} \mathrm{P}<0.05$ when compared with high nicotine.

KEYS: CN - Control, LN - Low Nicotine, HN - High Nicotine,

LNA - Low Nicotine + Quercetin, HNA - High Nicotine + Quercetin. 


\section{D A}

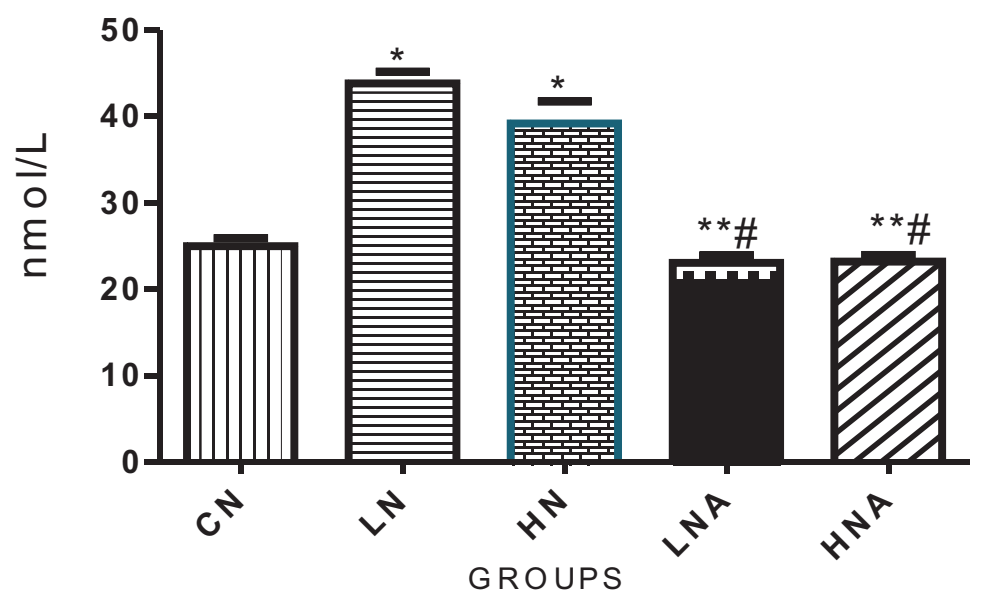

Figure 4: Effects of nicotine and quercetin on serum MDA levels in Wistar rats.

Values expressed as mean \pm SEM; $n=8 ;{ }^{* *} \mathrm{P}<0.05$ when compared with control,

${ }^{*} \mathrm{P}<0.05$ when compared with low nicotine, ${ }^{\#} \mathrm{P}<0.05$ when compared with high nicotine.

KEYS: CN - Control, LN - Low Nicotine, HN - High Nicotine,

LNA - Low Nicotine + Quercetin, HNA - High Nicotine + Quercetin.

\section{CATALASE}

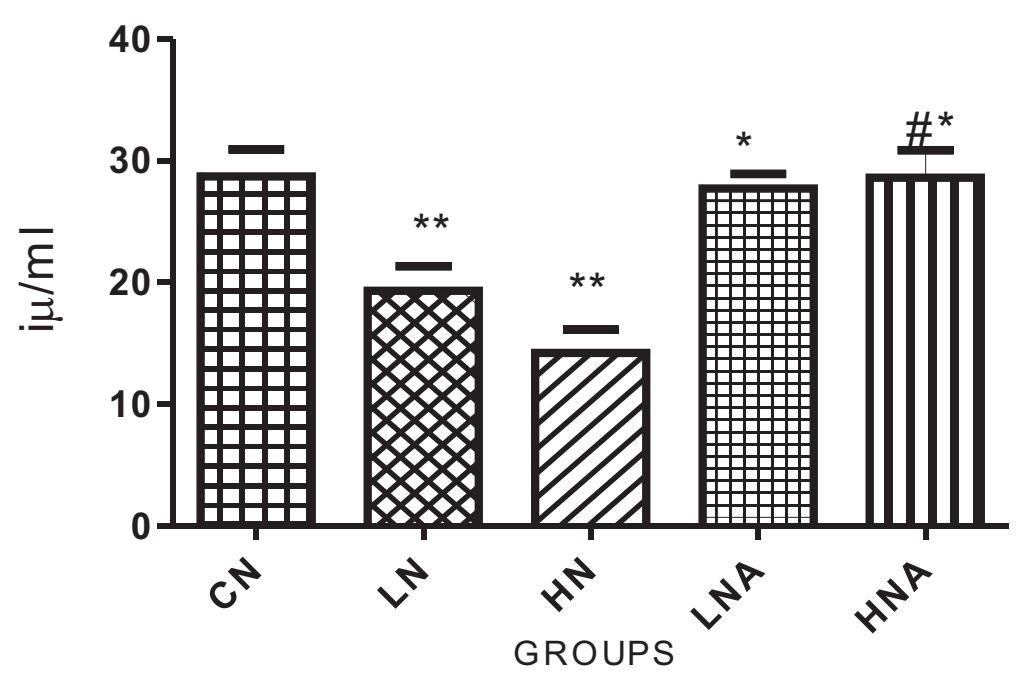

Figure 5: Effects of nicotine and quercetin on serum Catalase levels in Wistar rats. Values expressed as mean \pm SEM; $n=8 ;{ }^{* *} \mathrm{P}<0.05$ when compared with control,

${ }^{*} \mathrm{P}<0.05$ when compared with low nicotine, ${ }^{\#} \mathrm{P}<0.05$ when compared with high nicotine. KEYS: CN - Control, LN - Low Nicotine, HN - High Nicotine,

LNA - Low Nicotine + Quercetin, HNA - High Nicotine + Quercetin. 


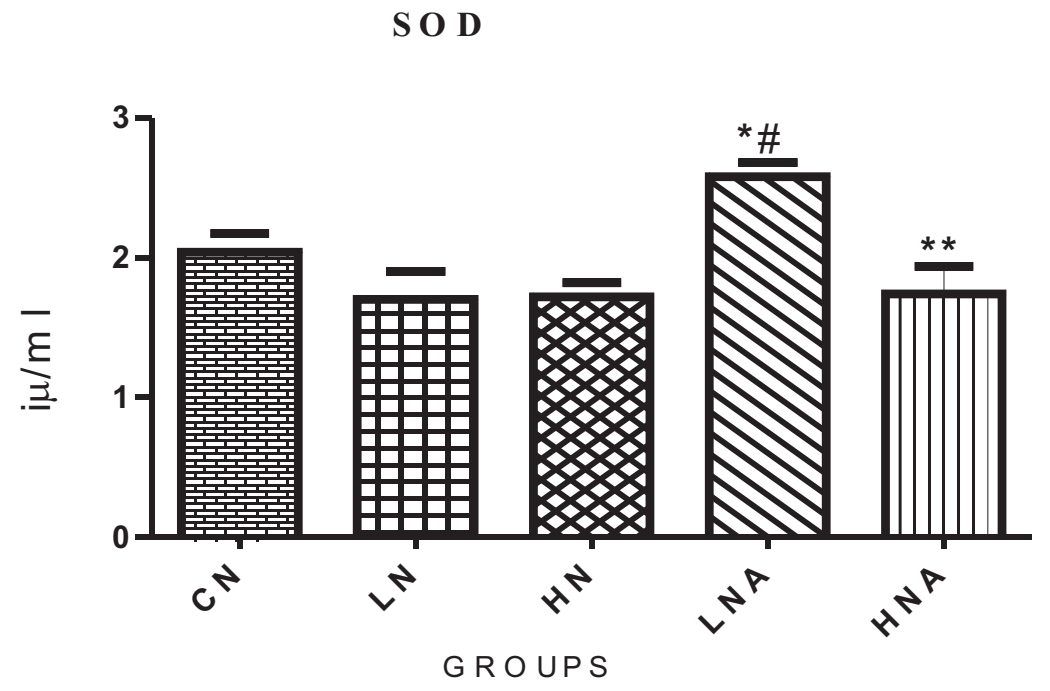

Figure 6: Effects of nicotine and quercetin on serum SOD levels in Wistar rats. Values expressed as mean \pm SEM; $n=8 ;{ }^{* *} \mathrm{P}<0.05$ when compared with control, ${ }^{*} \mathrm{P}<0.05$ when compared with low nicotine, ${ }^{\#} \mathrm{P}<0.05$ when compared with high nicotine. KEYS: CN - Control, LN - Low Nicotine, HN - High Nicotine,

LNA - Low Nicotine + Quercetin, HNA - High Nicotine + Quercetin. 